\title{
Validitas Soal Higher-Order Thinking Skill Matematika Berkonteks Kebencanaan untuk Siswa Sekolah Menengah Pertama
}

\author{
Fahlida Harnita ${ }^{1}$, Rahmah Johar ${ }^{1 *}$, M. Hasbi ${ }^{1}$, Sulastri $^{2}$ \\ ${ }^{1}$ Jurusan Pendidikan Matematika, Fakultas Keguruan dan Ilmu Pendidikan, Universitas Syiah Kuala \\ ${ }^{2}$ Jurusan Pendidikan Kimia, Fakultas Keguruan dan Ilmu Pendidikan, Universitas Syiah Kuala \\ *rahmah.johar@unsyiah.ac.id
}

\begin{abstract}
Abstrak
Upaya mitigasi bencana dalam pembelajaran matematika perlu dilakukan untuk menumbuhkan sikap sadar bencana pada siswa melalui soal higher order thinking skill (HOTS) matematika berkonteks kebencanaan. Salah satu upaya yang dapat dilakukan adalah merancang soal matematika dengan konteks kebencanaan. Tujuan penelitian ini yaitu untuk memperoleh soal HOTS matematika berkonteks kebencanaan untuk siswa Sekolah Menengah Pertama (SMP) yang memenuhi kriteria valid. Penelitian ini merupakan penelitian pengembangan yang dibatasi pada tahapan self evaluation dan expert review saja. Hasil dari penelitian ini adalah diperoleh 16 soal HOTS matematika berkonteks kebencanaan untuk siswa SMP yang valid baik dari aspek isi maupun konstruk. Konteks kebencanaan yang digunakan meliputi bencana kekeringan, tsunami, gempa bumi, gunung meletus, perubahan iklim, tanah longsor, kebakaran hutan, dan banjir. Implikasi penelitian ini yaitu soal-soal yang telah valid dapat digunakan oleh para guru dalam proses belajar mengajar di kelas.
\end{abstract}

Kata kunci: higher-order thinking skill, konteks kebencanaan, validasi soal

\begin{abstract}
Disaster mitigation efforts in learning mathematics need to be done to foster a disaster awareness attitude in students through higher-order thinking skills (HOTS) questions in mathematics with a disaster context. One effort that can be done is to design mathematics problems in a disaster context. This study aimed to obtain valid HOTS mathematics questions in the disaster context for junior high school students. This research is development research that is limited to the self-evaluation and expert review stages only. This study obtained 16 HOTS questions in mathematics with disaster context for junior high school students, which were valid both in terms of content and construct. The disaster context used includes drought, tsunami, earthquakes, volcanic eruptions, climate change, landslides, forest fires, and floods. The implication of this research is that valid questions can be used by teachers in the teaching and learning process in the classroom.
\end{abstract}

Keywords: disaster context, higher-order thinking skill, problem validation

Received: August 8, 2020 / Accepted: November 24, 2020 / Published Online: December 13, 2020

\section{Pendahuluan}

Letak suatu daerah sangat mempengaruhi tingkat kerentanan daerah tersebut terhadap bencana. Secara geografis, Indonesia yang terdiri dari ribuan pulau dikelilingi oleh Cincin Api Pasifik. Hal ini menjadikan Indonesia sebagai wilayah yang rawan bencana gempa bumi, tsunami, dan gunung meletus (Tondobala, 2011). 
Masyarakat yang tinggal di daerah rawan bencana harus berusaha untuk siap menghadapi bencana, mengantisipasi bencana, dan beradaptasi dengan bencana. Kegiatan tersebut dikenal sebagai upaya mitigasi bencana. Peraturan Pemerintah (PP) nomor 21 tahun 2008 menyebutkan bahwa mitigasi bencana menujukkan kepada serangkaian upaya untuk mengurangi risiko bencana, baik kesiapan secara mental dan kemampuan maupun pembangunan jangka panjang.

Mitigasi bencana dapat meningkatkan kesadaran kepada masyarakat terkait dengan penanggulangan bencana sejak dini (Prihatin, 2018). Upaya memperkecil risiko bencana dapat dilakukan dengan merubah perilaku manusia melalui perubahan pola pikir dan pembiasaan diri untuk selalu peduli pada lingkungan dan sadar bencana. Namun, upaya tersebut belum maksimal diterapkan pada semua aspek, terutama dalam bidang pendidikan.

Pendidikan menjadi salah satu sarana yang efektif untuk mengurangi risiko bencana yaitu dengan melakukan edukasi tentang mitigasi bencana dalam pembelajaran. Pengintegrasian dapat dilakukan dengan pemberian pemahaman terhadap siswa tentang kebencanaan dalam beberapa mata pelajaran (Rusilowati, Supriyadi, Binadja, \& Mulyani, 2012). Salah satunya yaitu dengan menggunakan konteks kebencanaan dalam pembelajaran matematika.

Konteks kebencanaan juga dapat menjadi ide dalam mengembangkan soal yang mendukung pembelajaran matematika. Soal yang dikembangkan mengikuti amanat dari kurikulum Indonesia yang dapat mengembangkan kecakapan abad ke-21 yaitu kreativitas, berfikir kritis, dan pemecahan masalah. Keterampilan tersebut dapat ditumbuhkan melalui soal Higher Order Thinking Skill (HOTS) (Dinni, 2018).

Soal HOTS merupakan suatu pertanyaan yang digunakan untuk mengukur keterampilan tingkat tinggi yang terdiri dari kemampuan menganalisis, mengevaluasi dan mengkreasi (Anderson \& Krathwohl, 2001). Menganalisis merupakan kemampuan melihat secara detail sesuatu yang utuh menjadi bagian-bagian dan mencari hubungan satu sama lain. Mengevaluasi merupakan kemampuan memberikan penilaian terhadap sesuatu dan mampu mempertanggungjawabkan pendapat tersebut. Sedangkan mengkreasi merupakan kemampuan menggabungkan beberapa komponen menjadi satu kesatuan yang utuh dan bersifat fungsional (Anderson \& Krathwohl, 2001).

Soal HOTS matematika berkonteks kebencanaan merupakan pertanyaan yang dapat mengukur keterampilan berfikir tingkat tinggi dan juga mengandung informasi serta permasalahan terkait dengan bencana. Soal HOTS matematika berkonteks kebencanaan dapat 
dikembangkan untuk keempat materi di Sekolah Menengah Pertama (SMP) yaitu bilangan, aljabar, geometri dan statistika dengan menggunakan konteks bencana kekeringan, tsunami, gempa bumi, gunung meletus, perubahan iklim, tanah longsor, kebakaran hutan, dan banjir.

Hasil penelitian yang telah dilakukan Nuzulidar, Johar, dan Sulastri (2019) menunjukan bahwa guru belum memiliki soal matematika dengan konteks kebencanaan. Penelitian tersebut juga menunjukkan bahwa hanya tiga siswa yang pernah membaca soal matematika dengan konteks kebencanaan. Soal matematika berkonteks kebencanaan pernah dikembangkan oleh Khalid dan Ali (2016), namun hanya terbatas pada satu soal, padahal soal dengan konteks kebencanaan membantu siswa untuk menumbuhkan kesadaran terhadap bencana dan pengetahuan tentang mitigasi bencana (Fatimah, Johar, \& Zubainur, 2020). Dengan demikian dapat disimpulkan bahwa soal matematika berkonteks kebencanaan masih terbatas dan perlu dikembangkan.

Penelitian sebelumnya telah banyak mengupayakan pengembangan soal dengan ciri HOTS tetapi belum mengakomodir konteks kebencanaan. Soal yang dimaksud menggunakan konteks lainnya yang berorientasi kepada potensi dan kearifan lokal daerah tertentu seperti Bumi Raflesia (Ramadianti, Syofiana, \& Mahyudi, 2018) dan rumah adat (Susanti, 2016).

Berdasarkan uraian di atas, penelitian ini bertujuan untuk memperoleh soal HOTS matematika berkonteks kebencanaan untuk siswa SMP yang memenuhi kriteria valid. Pertanyaan dalam penelitian ini adalah bagaimanakah validitas soal HOTS matematika berkonteks kebencanaan untuk siswa SMP?

\section{Metode}

Penelitian ini merupakan penelitian pengembangan berdasarkan Tessmer (1993) yang terdiri dari self evaluation, expert review, one to one, small group, dan field test. Self evaluation dilakukan dengan tujuan untuk mengetahui kebutuhan pengguna terhadap soal HOTS matematika berkonteks kebencanaan. Expert review dilakukan validasi terhadap soal untuk mendapatkan panilaian dan masukan dari para ahli. Sedangkan one-to-one dan small group dilakukan untuk mengetahui keterbacaan soal, serta field test dilakukan untuk menguji soal secara keseluruhan sehingga layak digunakan. Oleh karena tujuan penelitian ini adalah untuk mendapatkan soal yang valid dan peneliti kesulitan memotivasi siswa untuk menyelesaikan soal secara jujur melalui online pada masa pandemi covid-19, maka peneliti hanya menjalankan sebagian dari tahapan Tessmer yaitu self evaluation dan expert review saja. Tahapan pengembangan Tessmer dapat dilihat pada Gambar 1. 


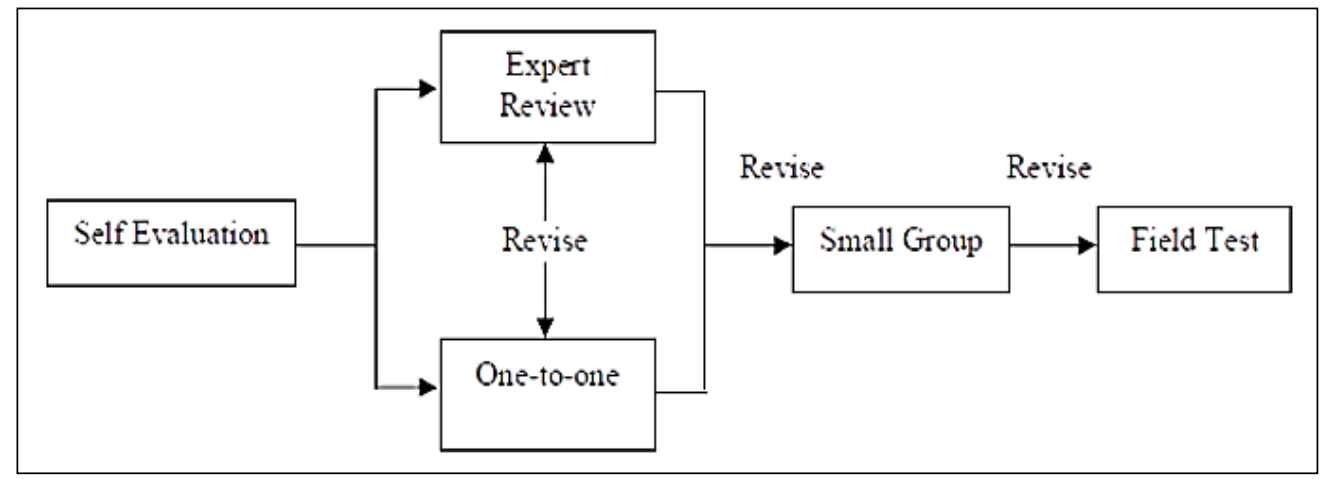

Gambar 1. Tahap pengembangan Tessmer

Tahap pertama yaitu self evaluation bertujuan untuk mengetahui apakah soal HOTS matematika berkonteks kebencanaan penting dan belum tersedia sesuai kebutuhan sehingga perlu dikembangkan. Pada tahapan ini, dilakukan dua langkah yaitu analisis dan perancangan.

Analisis merupakan kegiatan mengenal lebih dekat terhadap lingkungan yang menjadi tujuan pengembangan soal. Analisis dilakukan terhadap siswa, kurikulum, materi dan dokumen yang dianggap sesuai dengan pengembangan soal HOTS matematika berkonteks kebencanaan. Analisis terhadap siswa dilakukan untuk mengetahui apakah soal HOTS matematika berkonteks kebencanaan perlu dan sesuai untuk diterapkan pada siswa SMP. Analisis terhadap kurikulum dilakukan untuk mengetahui sejauh mana soal HOTS matematika berkonteks kebencanaan telah diintegrasikan kedalam kurikulum. Analisis terhadap materi dilakukan untuk mengetahui kecocokan antara materi matematika SMP dan konteks kebencanaan yang digunakan. Analisis terhadap dokumen bertujuan untuk menganalisis referensi yang dipakai dalam pengembangan soal HOTS matematika berkonteks kebencanaan. Analisis terhadap siswa, kurikulum, dan materi telah dilakukan sebelum memutuskan ide penelitian di mana hasilnya menjadi dasar dari penelitian ini. Setelah melakukan analisis terhadap dokumen yang menjadi referensi pengembangan soal HOTS matematika berkonteks kebencanaan, dilakukan perancangan soal yang mengacu pada referensi tersebut.

Perancangan merupakan proses pengembangan bahan ajar yang akan dievaluasi. Tahap perancangan bertujuan untuk mengembangkan prototype soal HOTS matematika berkonteks kebencanaan yang memenuhi karakteristik soal seperti yang telah dipelajari pada tahap analisis dokumen. Pada tahap ini, dirancang soal HOTS matematika berkonteks kebencanaan. Pengembangan soal dilakukan dengan memperhatikan tiga hal, yaitu isi, kontruksi dan bahasa.

Setelah melakukan tahap self evaluation, selanjutnya dilakukan tahap expert review. Tahap expert review bertujuan untuk mengevaluasi soal yang telah dikembangkan oleh validator (expert). Prototype I diberikan kepada validator untuk dilakukan validasi. Validator 
memberikan masukan terhadap prototype I. Selanjutnya dilakukan revisi terhadap prototype I dengan mempertimbangkan komentar dan saran dari validator. Validator yang dilibatkan dalam penelitian ini terdiri dari 4 orang, dari kalangan dosen dan guru yang berpengalaman dalam pengembangan perangkat pembelajaran dengan konteks kebencanaan, terlibat dalam penelitian tentang kebencanaan, dan pelatih peserta olimpiade serta pembuat soal olimpiade matematika tingkat sekolah dasar sampai perguruan tinggi.

Validitas soal diukur untuk dua aspek yaitu validitas teoritis yang terdiri dari validitas isi dan konstruk. Selain itu pada penelitian ini, ingin diukur aspek ketepatan bahasa. Hal ini bertujuan untuk mendapatkan soal yang siap untuk diuji coba apabila sudah memenuhi kriteria valid. Karakteristik validitas soal yang digunakan mengacu pada Lewy, Zulkardi, dan Aisyah (2009) seperti terlihat pada Tabel 1.

Tabel 1. Karakteristik validitas soal

\begin{tabular}{|c|c|c|}
\hline Isi & Konstruk & Bahasa \\
\hline $\begin{array}{l}\text { Soal tes mengukur } \\
\text { kemampuan berfikir } \\
\text { kritis sesuai dengan: } \\
\text { - Kompetensi Dasar } \\
\text { - Indikator } \\
\text { - Tujuan } \\
\text { Pembelajaran }\end{array}$ & $\begin{array}{l}\text { Soal sesuai dengan teori yang } \\
\text { mendukung dan kriteria: } \\
\text { - Mengembangkan } \\
\text { kemampuan menganalisis, } \\
\text { mengevaluasi, atau } \\
\text { mengkreasi } \\
\text { - Kaya dengan konsep } \\
\text { - Sesuai dengan level siswa } \\
\text { SMP } \\
\text { - Mengundang } \\
\text { pengembangan konsep } \\
\text { lebih lanjut }\end{array}$ & $\begin{array}{l}\text { - Sesuai dengan Pedoman } \\
\text { Umum Ejaan Bahasa } \\
\text { Indonesia (PUEBI) } \\
\text { - } \quad \text { Soal tidak berbelit-belit } \\
\text { - } \quad \text { Soal tidak mengandung } \\
\text { penafsiran ganda } \\
\text { - } \text { Batasan pertanyaan dan } \\
\text { jawaban jelas } \\
\text { - Menggunakan bahasa } \\
\text { umum }\end{array}$ \\
\hline
\end{tabular}

Setelah data yang diperlukan terkumpul, dilakukan analisis terhadap data tersebut. Teknik analisis data adalah teknik yang dilakukan untuk mengolah data sesuai dengan tujuan penelitian (Arikunto, 2010). Pada penelitian ini, teknik analisis data yang dilakukan adalah analisis walk through (Tessmer, 1993). Pada tahap expert review, peneliti mengorganisasikan kembali soal berdasarkan catatan validator melalui analisis deskriptif. Jika terjadi ketidakselarasan antara catatan validator yang satu dengan yang lain, maka data dari hasil validasi didiskusikan kembali dengan ahli tersebut untuk memaksimalkan informasi sehingga mencapai tingkat kejenuhan (redudansi) dimana tidak ada lagi data baru yang ditemukan. Selanjutnya peneliti bisa menggunakan data hasil validasi tersebut sebagai acuan untuk merevisi prototype sampai dinyatakan valid. 
Berdasarkan skala prioritas pada lembar validasi, maka revisi soal pada penelitian ini dibagi menjadi empat kategori revisi yaitu revisi besar, revisi sedang, revisi kecil, dan tanpa revisi. Adapun kriteria yang menjadi acuan revisi soal yang dilakukan peneliti disajikan pada Tabel 2.

Tabel 2. Kategori revisi

\begin{tabular}{ll}
\hline Banyak komponen tidak dipenuhi $(\mathbf{x})$ & Kategori revisi \\
\hline $9 \leq \mathrm{x} \leq 12$ & Revisi besar \\
\hline $5 \leq \mathrm{x} \leq 8$ & Revisi sedang \\
\hline $1 \leq \mathrm{x} \leq 4$ & Revisi kecil \\
\hline $\mathrm{x}<1$ & Tanpa revisi \\
\hline
\end{tabular}

\section{Hasil Penelitian}

Pada bagian ini dideskripsikan proses pengembangan soal HOTS matematika berkonteks kebencanaan pada tahap self evaluation dan expert review. Pada tahap self evaluation, dilakukan analisis dan perancangan soal. Analisis dilakukan untuk menghasilkan data berupa soal HOTS matematika berkonteks kebencanaan penting untuk dikembangkan dan terbatas. Perancangan soal dilakukan untuk merancang soal HOTS matematika berkonteks kebencanaan.

Hasil yang diperoleh pada tahap self evaluation berkaitan dengan analisis dan perancangan adalah perangkat soal berupa kisi-kisi soal HOTS matematika berkonteks kebencanaan untuk siswa SMP yang telah didiskusikan dengan tim penulis dan diuji keterbacaan soal kepada peserta ON-MIPA disebut sebagai prototype I. Soal yang dikembangkan sebanyak 16 soal HOTS matematika berkonteks kebencanaan yang terdiri dari 5 soal pada materi bilangan, 5 soal pada materi aljabar, 3 soal pada materi statistik, dan 3 soal pada materi geometri. Soal-soal memuat konteks bencana kekeringan sebanyak 1 soal, tsunami sebanyak 4 soal, gempa bumi sebanyak 2 soal, gunung meletus sebanyak 1 soal, perubahan iklim sebanyak 1 soal, banjir sebanyak 3 soal, tanah longsor sebanyak 2 soal, dan kebakaran sebanyak 2 soal.

Pada tahap expert review, prototype I diberikan kepada para validator untuk divalidasi berdasarkan komponen isi, konstruks, dan bahasa. Setelah para validator melakukan validasi terhadap soal, terdapat beberapa saran yang menjadi pertimbangan dalam merevisi prototype I. Dari soal-soal tersebut, terdapat 3 soal yang mengalami revisi besar, 11 soal mengalami revisi sedang, 3 soal mengalami revisi kecil, dan 1 soal tidak mengalami revisi. Soal yang mengalami revisi besar yaitu soal-1, soal-2, dan soal-3. Soal mengalami revisi sedang yaitu soal-6, soal-7, soal-10, soal-14, soal-16. Soal mengalami revisi kecil yaitu soal-4, soal-5, soal-9, soal-11, soal- 
12, soal-13, dan soal-15. Soal yang tidak mengalami revisi yaitu soal-8. Proses dan hasil validasi soal adalah sebagai berikut.

\section{Soal konteks kekeringan}

Soal 1 dengan konteks mitigasi bencana kekeringan berkaitan dengan materi operasi bilangan. Soal ini dikembangkan untuk memenuhi tujuan pembelajaran di mana siswa dapat menyelesaikan masalah yang berkaitan dengan operasi hitung bilangan bulat dengan tepat. Soal berada pada level C4 di mana soal dapat mengukur kemampuan menganalisis. Soal ini mengalami revisi besar karena tidak memenuhi sembilan komponen dari karakteristik validitas soal, yaitu soal sesuai dengan indikator dan tujuan pembelajaran, mengembangkan kemampuan menganalisis, mengevaluasi, atau mengkreasi, kaya dengan konsep, mengundang pengembangan konsep lebih lanjut, sesuai dengan PUEBI, tidak berbelit-belit, tidak mengandung penafsiran ganda, serta batasan pertanyaan dan jawaban jelas. Revisi yang dilakukan pada soal ini dapat dilihat pada Tabel 3.

Tabel 3. Proses revisi soal-1

\begin{tabular}{|c|c|c|}
\hline Soal Prototype I & Komentar Para Validator & Keputusan Revisi \\
\hline $\begin{array}{l}\text { Masyarakat Tasikmalaya } \\
\text { yang kekurangan air } \\
\text { bersih saat musim } \\
\text { kemarau menerima } \\
\text { distribusi air bersih } \\
\text { sebanyak } 220.000 \text { liter } \\
\text { dari Polres dan } 335.000 \\
\text { liter dari BPBD } \\
\text { setempat. Air bersih } \\
\text { tersebut didistribusikan } \\
\text { ke daerah-daerah yang } \\
\text { dinilai sudah mengalami } \\
\text { kekeringan cukup parah. } \\
\text { Pendistribusian } \\
\text { dilakukan dengan } \\
\text { menggunakan kendaraan } \\
\text { pengangkut air yang } \\
\text { berkapasitas } 5000 \text { liter. } \\
\text { Setiap daerah menerima } \\
\text { tiga kali pengangkutan } \\
\text { dengan volume air } \\
\text { maksimal di setiap } \\
\text { pengangkutan. Berapa } \\
\text { banyak daerah yang } \\
\text { mendapatkan bantuan air } \\
\text { bersih? }\end{array}$ & $\begin{array}{l}\text { Validator } 2 \\
\text { Konteks soal diarahkan kepada } \\
\text { mitigasi bencana kekeringan. } \\
\text { Kekeringan disebabkan oleh } \\
\text { penguapan air tanah yang lebih } \\
\text { cepat karena adanya } \\
\text { pemanasan global. Penggunaan } \\
\text { sumber energi berlebihan dan } \\
\text { asap kendaraan bermotor } \\
\text { merupakan pemicu pemanasan } \\
\text { global. } \\
\text { Validator } 3 \\
\text { Kata tanya yang digunakan } \\
\text { pada soal belum menuntut } \\
\text { uraian dan soal belum } \\
\text { mengukur HOTS. } \\
\text { Validator } 4 \\
\text { Agar kalimat soal tidak terlalu } \\
\text { panjang, kalimat-2 dan } \\
\text { kalimat-3 dapat digabungkan. }\end{array}$ & $\begin{array}{l}\text { Kekeringan akibat } \\
\text { pemanasan global } \\
\text { melanda masyarakat di } \\
\text { Kabupaten Tasikmalaya, } \\
\text { Jawa Barat. Badan } \\
\text { Penanggulangan Bencana } \\
\text { Daerah (BPBD) } \\
\text { menyalurkan bantuan } \\
\text { berupa } 277.000 \text { liter air } \\
\text { bersih, } 3.855 \text { karung } \\
\text { beras, dan } 7.800 \text { dus mi } \\
\text { instan. Setiap desa rata- } \\
\text { rata ditempati oleh } 50 \\
\text { Kepala Keluarga (KK) } \\
\text { yang memperoleh ketiga } \\
\text { jenis bantuan tersebut } \\
\text { masing-masing sama } \\
\text { banyak. Berapa desa } \\
\text { paling banyak yang } \\
\text { mungkin untuk } \\
\text { mendapatkan bantuan? } \\
\text { Tentukan juga banyak air } \\
\text { bersih, beras dan mi } \\
\text { instan yang diperoleh } \\
\text { setiap KK pada masing- } \\
\text { masing desa! }\end{array}$ \\
\hline
\end{tabular}




\section{Soal konteks perubahan iklim}

Soal 7 konteks perubahan iklim berkaitan dengan materi penyajian data. Soal ini dikembangkan untuk memenuhi tujuan pembelajaran yaitu siswa dapat menafsirkan data yang disajikan dalam bentuk diagram garis dengan benar. Soal ini berada pada level C6 karena mengukur kemampuan mengkreasi. Soal ini mengalami revisi sedang karena tidak memenuhi enam komponen dari karakteristik validitas soal, yaitu soal harus sesuai dengan indikator dan tujuan pembelajaran, mengembangkan kemampuan menganalisis, mengevaluasi, atau mengkeasi, soal dapat mengundang pengembangan konsep lebih lanjut, sesuai dengan PUEBI, serta menggunakan bahasa umum. Revisi yang dilakukan pada soal ini dapat dilihat pada Tabel 9.

Tabel 4. Proses revisi soal-7

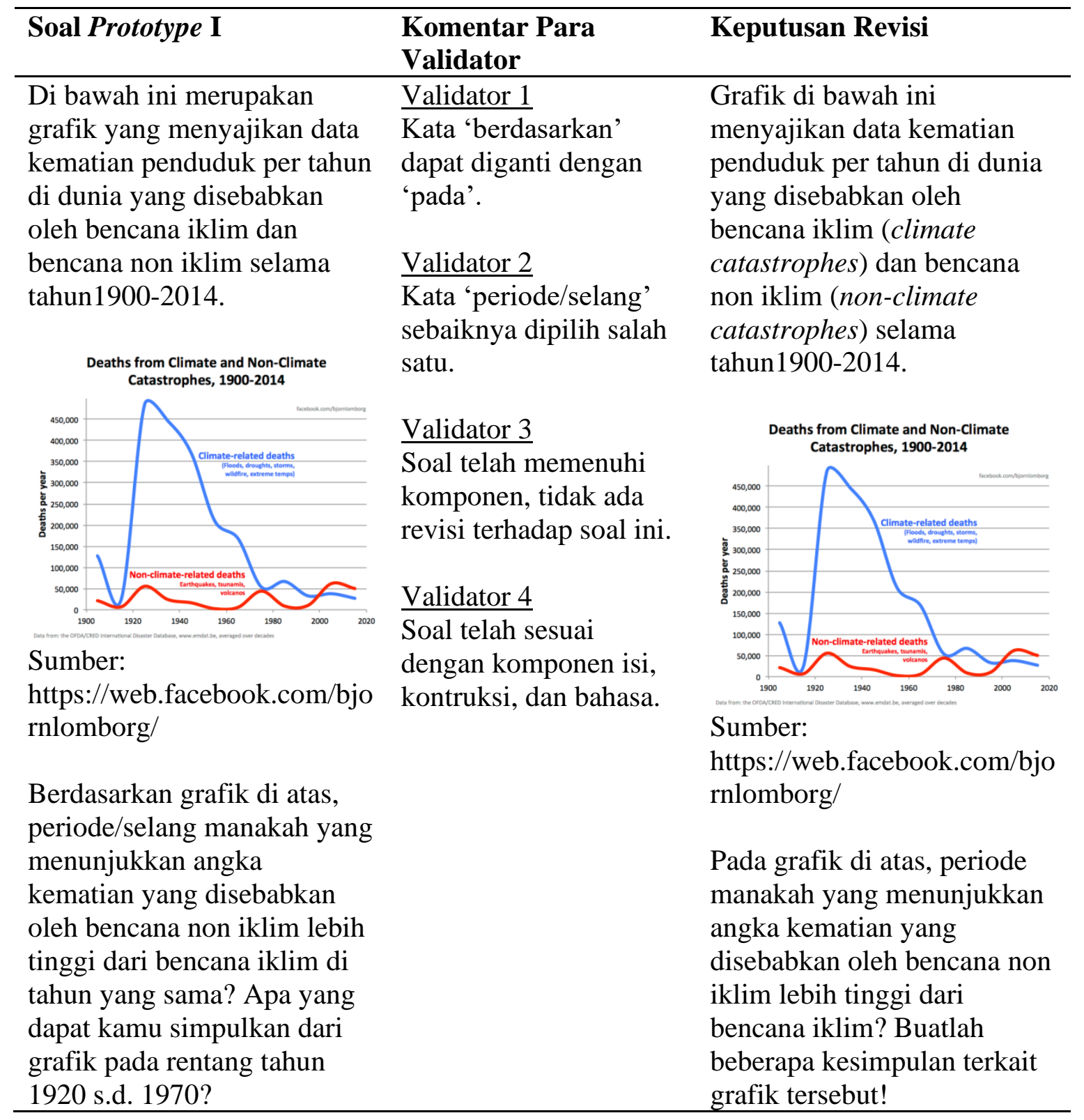




\section{Soal konteks tanah longsor}

Soal 11 konteks mitigasi bencana tanah longsor berkaitan dengan materi persamaan garis lurus. Soal ini dikembangkan untuk memenuhi tujuan pembelajaran yaitu siswa dapat menentukan gradien dari suatu garis dengan tepat. Soal ini berada pada level C5 karena mengukur kemampuan mengevaluasi. Soal ini mengalami revisi kecil karena tidak memenuhi dua komponen dari karakteristik validitas soal, yaitu soal tidak berbelit-belit dan tidak mengandung penafsiran ganda. Revisi yang dilakukan pada soal ini dapat dilihat pada Tabel 6.

Tabel 5. Proses revisi soal-11

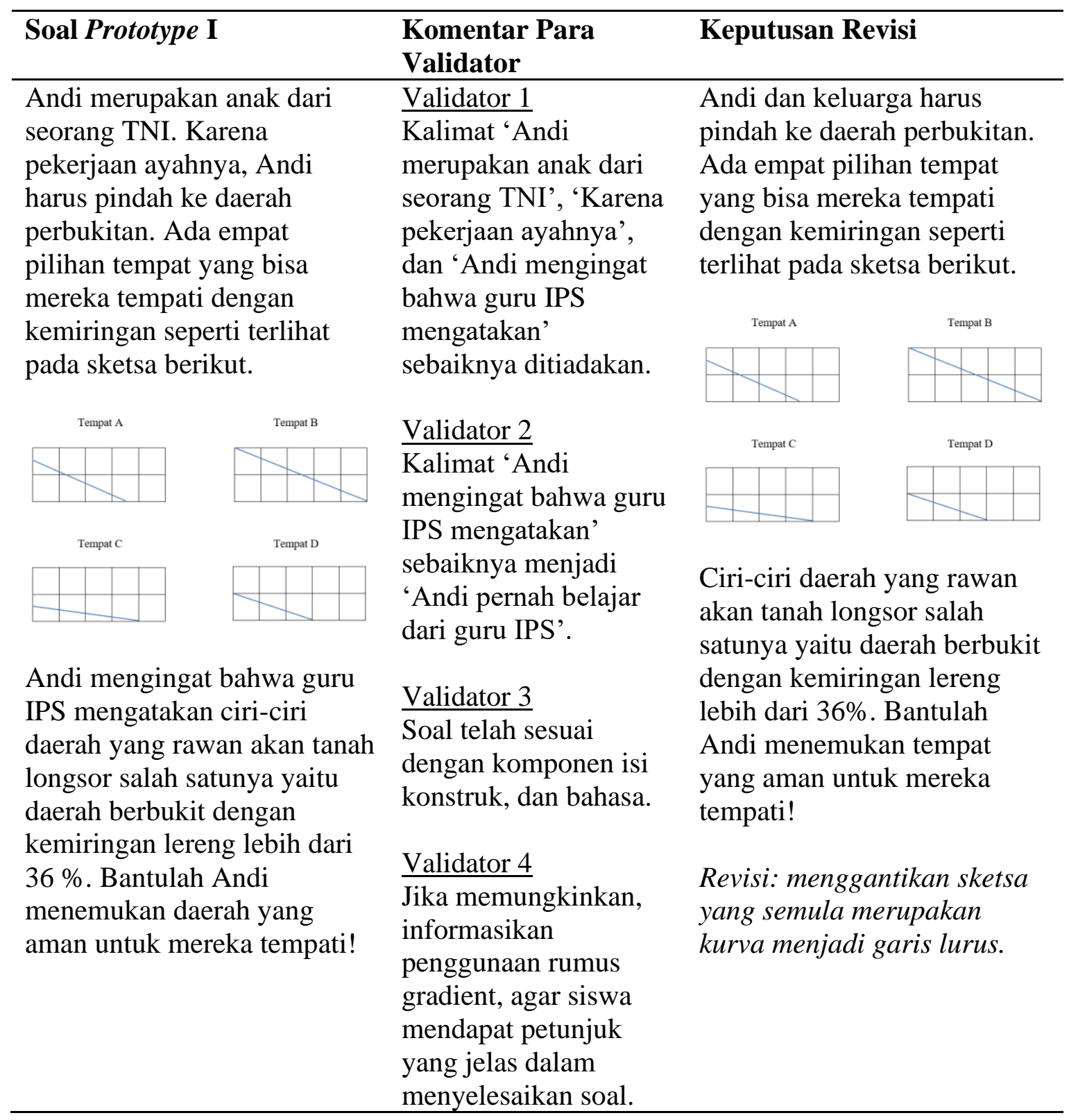

\section{Pembahasan}


Pada penelitian ini, dikembangkan 16 soal HOTS matematika berkonteks kebencanaan yang memenuhi kriteria valid, karena mencapai validitas teoritis (logis) yang memenuhi validitas isi (content validity) dan validitas konstruk (construct validity) (Arikunto, 2010). Berdasarkan hasil analisis terhadap siswa, diperoleh informasi bahwa soal HOTS matematika berkonteks kebencanaan perlu dan sesuai diterapkan pada siswa SMP. Soal matematika berkonteks kebencanaan diperlukan untuk meningkatkan kemampuan literasi siswa dan menumbuhkan kesadaran terhadap bencana (Nuzulidar, et al., 2019). Shadiq (2016) juga mengatakan bahwa pembelajaran mitigasi bencana sangat penting untuk diajarkan pada siswa. Sekolah merupakan lembaga pendidikan formal yang efektif dalam melaksanakan pendidikan penanggulangan bencana (Arifa, 2018). Banyak SMP di Jepang sudah menerapkan pendidikan pencegahan bencana yang sistematis dan terencana (Shirahata, 2012). Dengan demikian dapat disimpulkan bahwa soal HOTS matematika berkonteks kebencanaan perlu dan sesuai untuk siswa SMP sehingga perlu dikembangkan.

Hasil analisis terhadap kurikulum, ditemukan bahwa pelajaran kebencanaan belum masuk dalam kurikulum pendidikan formal dan nonformal seperti yang termuat dalam Rancangan Qanun Aceh Tahun 2019. Soal HOTS matematika berkonteks kebencanaan juga belum diintegrasikan secara maksimal dalam buku paket matematika SMP. Soal yang melibatkan konteks kebencanaan masih sangat terbatas, begitu pula dengan soal HOTS. Pada buku paket SMP, hanya didapati satu soal yang tersedia yaitu pada buku paket kelas VIII semester II materi persamaan linier dua variabel (As'ari, Tohir, Valentino, Imron, Taufiq, Hariarti, \& Lukmana, 2014). Berdasarkan hal tersebut, soal HOTS matematika berkonteks kebencanaan perlu dikembangkan agar ketersediaan soal lebih mencukupi.

Analisis terhadap materi dilakukan dengan mengidentifikasi materi-materi pembelajaran berdasarkan kurikulum 2013 untuk tingkat SMP yang terdiri dari bilangan, aljabar, geometri, dan statistik. Materi ini dipilih dengan dasar bahwa materi dapat dikaitkan dengan konteks kebencanaan. Jenis soal yang mungkin dikembangkan adalah soal non objektif (uraian) karena dapat menuntut kemampuan siswa dalam mengorganisasikan jawaban dengan kalimat-kalimat sendiri dan mengukur kemampuan HOTS (Rahman, Ofianto, \& Yetferson, 2019).

Berdasarkan analisis terhadap dokumen berupa referensi yang membahas tentang kemampuan HOTS, indikator HOTS yang digunakan pada penelitian ini adalah indikator yang dikemukakan oleh Anderson dan Krathwohl (2001) yang meliputi kemampuan menganalisis, mengevaluasi, dan mengkreasi. Soal yang dikembangkan adalah mengukur 
kemampuan menganalisis, mengevaluasi dan mengkreasi serta melibatkan pengintegrasian konteks kebencanaan. Konteks kebencanaan yang digunakan dalam soal HOTS meliputi delapan konteks bencana utama yaitu bencana kekeringan, tsunami, gempa bumi, gunung meletus, perubahan iklim, tanah longsor, kebakaran hutan, dan banjir. Setelah melakukan analisis terhadap dokumen yang menjadi referensi untuk pengembangan soal HOTS matematika berkonteks kebencanaan, dilakukan perancangan soal yang mengacu pada referensi tersebut.

Soal HOTS berkonteks kebencanaan yang dirancang mengalami berbagai revisi. Dalam merevisi soal, dilakukan perbaikan terhadap soal-soal yang belum memenuhi indikator HOTS. Menurut validator, penyelesaian soal masih terlalu singkat dan tidak memenuhi keterampilan HOTS. Karakteristik soal HOTS adalah mengukur kemampuan menganalisis, mengevaluasi dan mengkreasi (Anderson dan Krathwohl, 2001). Hal serupa juga dilakukan Nisa, Widiastuti, dan Hamid (2018) yang merevisi soal karena soal-soal sebelum revisi belum mencerminkan soal HOTS.

Revisi juga dilakukan pada soal yang memiliki kalimat yang terlalu panjang. Selaras dengan penelitian yang dilakukan Susanti (2016), beberapa siswa berkomentar bahwa soal yang memuat informasi terlalu banyak membuat mereka bingung. Validator juga menyarankan kalimat soal harus efektif sehingga dapat mengungkapkan gagasan pemakainya secara tepat dan dapat dipahami secara tepat pula oleh pembacanya (Riswati, 2015).

Pergantian kata atau frasa juga dilakukan dalam revisi soal sehingga kalimat menjadi lebih komunikatif dan tidak ambigu. Kalimat yang ambigu mempunyai makna lebih dari satu sehingga dapat menyebabkan ketidakjelasan. Agar kalimat yang disusun dapat diterima dengan baik oleh pembaca, kalimat harus menggunakan bahasa Indonesia yang baik dan benar, baku dan sesuai dengan PUEBI (Riswati, 2015). Validator juga meminta perbaikan terhadap beberapa kata yang mengalami kesalahan ketik karena menurut Khaerudin (2017), kesalahan ketik akan mempengaruhi validitas soal.

Soal-soal HOTS matematika berkonteks kebencanaan penting untuk dikembangkan. Dengan begitu, pemahaman tentang bencana pada siswa dapat meningkat dan pengetahuan mitigasi bencana akan tertanam pada siswa (Hayudityas, 2020). Selain itu, siswa lebih senang dalam belajar karena dapat menyelesaikan masalah yang lebih dekat dengan dunia siswa (Purwanti, 2012). Soal-soal yang telah valid dapat digunakan oleh para guru dalam proses belajar mengajar di kelas. Penelitian ini merupakan bagian awal dari tahapan pengembangan model Tessmer (1993) yaitu self evaluation dan expert review. Peneliti berikutnya diharapkan 
dapat melanjutkan tahapan pengembangan yaitu one to one, small group, dan field test serta menguji validitas soal secara empiris.

\section{Simpulan}

Penelitian ini telah menghasilkan soal HOTS matematika berkonteks kebencanaan untuk siswa SMP yang valid sebanyak 16 soal. Dari soal-soal tersebut, terdapat 3 soal yang mengalami revisi besar, 11 soal mengalami revisi sedang, 3 soal mengalami revisi kecil, dan 1 soal tidak mengalami revisi. Soal yang mengalami revisi besar yaitu soal-1 (bilangan), soal-2 (bilangan), dan soal-3 (aljabar). Soal mengalami revisi sedang yaitu soal-6 (bilangan), soal-7 (statistika), soal-10 (bilangan), soal-14 (statistika), soal-16 (geometri). Soal mengalami revisi kecil yaitu soal-4 (aljabar), soal-5 (bilangan), soal-9 (geometri), soal-11 (aljabar), soal-12 (aljabar), soal-13 (aljabar), dan soal-15 (geometri). Soal tersebut dikembangkan melalui tahapan self evaluation dan expert review untuk mendapatkan soal yang mencapai validitas teoritis mencakup validitas isi dan validitas konstruksi.

\section{Referensi}

Anderson, L. W., \& Krathwohl, D. R. (2001). A Taxonomy for learning, teaching, and assesing; A revision of Bloom's taxonomy of education objectives. New York: Addison Wesley Lonman Inc.

Arifa, F. N. (2018). Mitigasi bencana pada sektor pendidikan formal. Info Singkat, 10(20), 1318.

Arikunto, S. (2010). Prosedur penelitian suatu pendekatan praktek. Jakarta: Rineka Cipta.

As'ari, A. R., Tohir, M., Valentino, E., Imron, Z., Taufiq, I., Hariarti, N. S., \& Lukmana, D. A. (2014). Matematika SMP/MTs kelas VIII semester 2. Jakarta: Kemdikbud.

Dinni, H. N. (2018). HOTS (High Order Thinking Skills) dan kaitannya dengan kemampuan literasi matematika. PRISMA, Prosiding Seminar Nasional Matematika, 1(1), 171-172.

Fatimah, S., Johar. R., \& Zubainur, C. M. (2020). Students' logical mathematical intelligence in completing mathematical problems with natural disaster context. Journal of Physics: Conference Series, 1470, 012022. https://doi.org/10.1088/1742-6596/1470/1/012022.

Hayudityas, B. (2020). Pentingnya penerapan pendidikan mitigasi bencana di sekolah untuk mengetahui kesiapsiagaan peserta didik. Jurnal Edukasi Nonformal, 1(2), 96.

Khaerudin. (2017). Administrasi, analisis butir, dan kaidah penulisan tes. Jurnal Madaniah, 12(1), 97-128.

Khalid, M., \& Ali, D. P. (2016). Inculcating tsunami awareness in a mathematics lesson: Improving students' collaborative problem solving via Lesson Study. Southeast Asian Mathematics Education Journal, 6(1), 19- 31.

Lewy, Zulkardi, \& Aisyah, N. (2009). Pengembangan soal untuk mengukur kemampuan berpikir tingkat tinggi pokok bahasan barisan dan deret bilangan di kelas IX akselerasi SMP Xaverius Maria Palembang. Jurnal Pendidikan Matematika, 3(2), 14-28. https://doi.org/10.22342/jpm.3.2.326. 
Nisa, N. K., Widyastuti, R., \& Hamid, A. (2018). Pengembangan instrumen assessmen Higher Order Thinking Skill (HOTS) pada lembar kerja peserta didik kelas VII SMP. Prosiding Seminar Nasional Matematika dan Pendidikan Matematika, 1(2), 543-556.

Nuzulidar, Johar, R., \& Sulastri. (2019). Teacher's and student's needs for mathematical problems in disaster context. Infinity Journal, 8(2), 239-246. https://doi.org/10.22460/infinity.v8i2.p239-246.

Prihatin, R. B. (2018). Masyarakat sadar bencana: Pembelajaran dari Karo, Banjarnegara, dan Jepang. Aspirasi: Jurnal Masalah-Masalah Sosial, 9(2), 222-223. https://doi.org/10.46807/aspirasi.v9i2.1106.

Purwanti, A. D. (2012). Penerapan pendekatan kontekstual untuk meningkatkan minat belajar siswa pada pembelajaran IPA di sekolah dasar. Jurnal Ilmiah Guru "COPE”, 16(2), 1-6.

Rahman, A., Ofianto, \& Yetferson, R. B. (2019). Pengembangan instrumen tes Higher Order Thinking Skills (HOTS) pada mata pelajaran sejarah Indonesia. Pakar Pendidikan, 17(1), 50 .

Ramadianti, W., Syofiana, M., \& Mahyudi. (2018). Pengembangan soal matematika openended berkonteks bumi rafflesia. Supremum Journal of Mathematics Education, 2(1), 816.

Retnawati, H. (2018). Desain pembelajaran matematika untuk melatih Higher Order Thinking Skills. Yogyakarta: UNY Press.

Riswati. (2015). Penggunaan kalimat efektif dalam karya tulis ilmiah mahasiswa. Riksa Bahasa, 1(2), 2.

Rusilowati, Supriyadi, Binadja, \& Mulyani. (2012). Mitigasi bencana alam berbasis pembelajaran bervisi science environment technology and society. Jurnal Pendidikan Fisika Indonesia, 8(1), 51-60.

Shadiq, F. (2016). How can SEAMEO QITEP in Mathematics help indonesian mathematicsteachers to help their students to be independent learners in the case of Disaster Risk Reduction (DRR)? Southeast Asian Mathematics Education Journal, 6(1), 3-18.

Shirahata, K. (2012). Tsunami disaster prevention education in Kesennuma City: Past, present, future. The Role of Education for Natural Disasters, 2-8. Diambil dari http://www.criced.tsukuba.ac.jp/math/apec/ICME12/Lesson_Study_set/The_Role_of_E ducation_for_Natural_Disasters.pdf.

Susanti, E. (2016). Pengembangan soal matematika TIMSS menggunakan konteks rumah adat untuk siswa sekolah menengah pertama. Jurnal Pendidikan Matematika, 10(2), 1-21. https://doi.org/10.22342/jpm.10.2.3631.53-74.

Tessmer, M. (1993). Planning and conducting formative evaluations: Improving the quality of education and training. London: Kogan Page.

Tondobala, L. (2011). Pemahaman tentang kawasan rawan bencana dan tinjauan terhadap kebijakan dan peraturan terkait. Jurnal Sabua, 3(1), 58. 